\title{
Apresentação à tradução do texto “História negra, história oral e genealogia", de Alex Haley
}

\author{
Verena Alberti* \\ ORCID iD 0000-0003-2145-7870 \\ Universidade do Estado do Rio de Janeiro, Centro de Educação e Humanidades, Rio de Janeiro, Brasil
}

O texto que se segue é uma palestra que o escritor norte-americano Alex Haley (1921-1992) proferiu em 10 de novembro de 1972, durante um jantar no Sétimo Colóquio Anual de História Oral da Associação de História Oral norte-americana, em Austin, Texas. ${ }^{1}$ No ano seguinte, ele foi publicado no primeiro número da Oral History Review, periódico da mesma associação. E desde 1998 ele é o primeiro capítulo da coletânea The Oral History Reader, organizada por Robert Perks e Alistair Thomson. ${ }^{2}$

Ainda que escrito há 40 anos, o texto é muito atual. Ele explica como o autor afro-americano chegou a suas raízes, em Gâmbia - percurso que está na origem de seu romance Roots: the saga of an american family (1976) (traduzido no Brasil como Negras raizes pela Editora Record), que recebeu o prêmio Pulitzer em 1977. O romance sobre o qual se baseou o seriado homônimo de sucesso - inspirou muitas pessoas a procurarem suas raízes em África.

No Brasil, muitas iniciativas têm evidenciado a importância do registro e da difusão de histórias e memórias de pessoas negras. É o caso dos podcasts Vidas Negras e História Preta, por exemplo. ${ }^{3}$ O romance Água de barrela, de Eliana Alves Cruz,

Professora da Universidade do Estado do Rio de Janeiro (UERJ). Doutora em Literatura pela Universitat Gesamthochschule Siegen (UGS), Alemanha. E-mail: verenalberti@gmail.com.

1 Uma parte do áudio desse "dinner speech" pode ser encontrada com sua respectiva transcrição no site UNT Digital Library. Disponível em: https://digital.library.unt.edu/ark:/67531/metadc953743/m1/. Acesso em: 12 maio 2021.

2 PERKS, Robert; THOMSON, Alistair (Ed.). The Oral History Reader. 3. ed. Londres/Nova York: Routledge, 2016. Trata-se de coletânea de artigos publicada pela primeira vez em 1998.

3 Vidas Negras - Disponível em: https://tiagorogero.com/vidas-negras-podcast/. Acesso em 12 maio 2021. História Preta - Disponível em: https://www.b9.com.br/shows/historiapreta/. Acesso em: 12 maio 2021. 
publicado em 2018, faz lembrar o percurso de Haley: remontando à deportação para o Brasil de dois jovens em 1850, a autora busca suas raízes em Cachoeira, no Recôncavo Baiano. ${ }^{4}$ No capítulo final, "Sobre como este livro aconteceu", ela também se refere à Pedra de Roseta.

A pesquisa de Haley recebeu algumas críticas: o autor teria ouvido do griot, em Gâmbia, justamente o que queria ouvir... As críticas foram mencionadas por Robert Perks e Alistair Thomson, que, ainda assim, decidiram manter o texto aqui traduzido na $3^{\text {a }}$ edição do The Oral History Reader, de 2016, pois, segundo eles, ele evoca a paixão e o compromisso no trabalho com a história oral e lembra que esse trabalho explora um vasto repertório de tradiçóes que envolve memórias familiares, comunitárias e nacionais. Uma matéria publicada no jornal britânico The Guardian, em fevereiro de 2017, por ocasiáo do $25^{\circ}$ aniversário da morte de Haley, também lembrou essas críticas, considerando-as, contudo, inoportunas. ${ }^{5}$

Uma das principais contribuiçóes do texto de Haley consiste em deixar muito evidente a pertinência da tradição oral como fonte para o estudo do passado.

Duas observaçóes ainda caberiam ser feitas:

1) Ali onde Alex Haley se refere à história oral talvez o mais adequado seria falarmos de tradição oral. A "transmissão física" que ele menciona a certa altura do texto e que muito provavelmente consiste na "transmissão", de geração em geração, de conhecimentos - aqueles "transmitidos" entre seus familiares e aqueles "transmitidos" por griots - é bem diferente das narrativas de experiência pessoal e das conversas que registramos em nossas entrevistas de história oral, ainda que essas últimas, com certeza, tenham "'pedaços' de tradição oral”, como já pude escrever em artigo publicado em outro número desta revista. ${ }^{6}$ (E optei por escrever "transmissão" entre aspas porque não se trata de uma mera repetição de conhecimentos; a contingência também determina como conhecimentos são narrados e percebidos).

2) As experiências norte-americanas da diáspora e da escravidão são muito semelhantes às que ocorreram em outras regiōes das Américas - e isso se aplica especialmente à violência física e simbólica. Mas precisamos também atentar para as diferenças. A partir dos anos 1980, estudos têm apontado para a existência de

4 CRUZ, Eliana Alves. Água de barrela. Rio de Janeiro: Malê, 2018.

5 DUGDAL, John. Roots of the problem: the controversial history of Alex Haley's book. The Guardian, 9 fev. 2017. Books blog. Disponível em: https://www.theguardian.com/books/booksblog/2017/feb/09/ alex-haley-roots-reputation-authenticity. Acesso em: 12 maio 2021.

6 ALBERTI, Verena. Tradição oral e história oral: proximidades e fronteiras. História Oral, v. 8, n.1, p. 1128, jan./jun. 2005. Disponível em: https://revista.historiaoral.org.br/index.php/rho/article/view/113. Acesso em: 12 maio 2021. 
famílias escravas na América portuguesa e, a partir de 1822, no Brasil, e também em algumas regióes da América do Norte. Assim, a exceção representada pelo antepassado de Alex Haley, que, diferentemente de outros escravizados, pôde constituir família, talvez se deva ao fato de ter sido levado a uma plantation em Virgínia, uma colônia do Sul, onde famílias escravas eram raras.

O relato que se segue é denso e emocionante. Além de tudo, ele nos faz pensar em nossas escolhas pessoais e profissionais, mistos de acaso e causa. A tradução de Alice Faria não apaga as condiçóes de enunciação, mantendo imprecisóes e repetiçóes do discurso original, que, em certo sentido, é também um texto literário. 